\title{
UTILIZATION OF NEEM LEAF MEAL: EFFECT ON GROWTH RESPONSE, HAEMATOLOGY AND SERUM BIOCHEMISTRY OF RABBIT DOES
}

\author{
UBUA, J. A., AL-ISAH, W., INUWA, I., ABDULLAHI, B. L. AND OZUNG, P.O \\ (Received 14December 2018; Revision Accepted 23January 2019)
}

\begin{abstract}
This study determined the effect of Neem Leaf Meal (NLM) based - diets on growth response, haematological and serum biochemical indices of female rabbits (does). Twenty four (24) weaned rabbits ( 5 - 6 weeks old with average body weight of $600 \pm 1.05 \mathrm{~g}$ ) were used. The NLM was included in the diets at $0,5,10$, and $15 \%$ levels as treatments $T_{1}, T_{2}, T_{3}$, and $T_{4}$, respectively. The rabbits were divided into four groups of six (6) each and randomly assigned to experimental diets using a Completely Randomized Design (CRD). Water was provided ad libitum and the rabbits were housed in disinfected wooden hutches for 56 days. Data on growth response, haematological and serum biochemical indices were collected and analysed using analysis of variance (ANOVA). Results revealed that the growth performance parameters showed significant $(P<0.05)$ differences between dietary treatments with progressive decrease in values as the levels of NLM inclusion increased across the diets. The final weight gain ranged between 860 and $970 \mathrm{~g} / \mathrm{rabbit}$. The total weight gain was between 310 and $380 \mathrm{~g} / \mathrm{rabbit}$, total feed intake ranged between 2150 and $2221 \mathrm{~g} /$ rabbit while FCR ranged between 5.84 and 6.94. Growth parameters beyond $10 \%$ inclusion level were least compared with values in the control diet. The haematological indices showed that all parameters were significantly $(P<0.05)$ affected by dietary treatments and within the normal ranges for apparently healthy rabbits. The serum biochemical indices were within normal ranges but not significantly affected $(P>0.05)$ by dietary treatments. The study concluded that $10 \%$ NLM can be included in the diets meant for rabbits without fear of compromising growth performance and blood characteristics.
\end{abstract}

KEY WORDS: Neem, female rabbit, growth, blood indices

\section{INTRODUCTION}

Scarcity of feed resources has been the main limitation in the production of livestock products to meet the animal protein requirements of humans and other industrial needs. Due to serious problems posed by the stiff competition for energy and proteinfeed stuffs, between humans and livestock, other available but neglected cheaper and novel feed resources have been focused areas of recent researches (Mahmud et al., 2015, Ozung et al., 2017). The conventional cereal and vegetable protein sources used in animal feeds are under pressure of competition through their use in human diets (Ogbuewu et al., 2010). The conventional vegetable protein sources such as soybean and groundnut cake are very expensive in developing countries like Nigeria due to high exchange rate (Esonu, 2006). Therefore, to develop balanced and economical feeds to compliment and possibly replace the scarce supplies from the expensive conventional sources, there is the need to search for alternative and readily available cheaper feed stuffs that are not directly consumed by man. Extant research has shown that feed alone accounts for about $60-80 \%$ of the total cost of production. There is therefore an urgent need for alternative locally and cheap sources of feed ingredients particularly those that do not attract competition in consumption between humans and livestock or have no direct relevance in human food chain. One of such possible sources of cheap feed stuff is neem leaf meal.

Inadequate supply of protein from traditional livestock such as cattle, sheep, goats, pigs and poultry have led to a shift of emphasis toward the rearing and production of micro livestock species like rabbits. Rabbit production is a veritable way of alleviating animal protein deficiency in Nigeria (Unigwe et al., 2009). Rabbit meat is healthy as it is low in cholesterol $(50 \mathrm{~g} / 100 \mathrm{~g})$, fat $(4 \mathrm{~g} / 100 \mathrm{~g})$ and energy $(124 \mathrm{Kcal} / 100 \mathrm{~g})$ but high in protein $(22,1100 \mathrm{~g})$ (Aduku and Olukosi, 1990). The meat has complete amino acid profile, it has good flavour and can be digested easily (Cheeke, 1986).

Neemleaf meal is not only a good source of protein, minerals and vitamins for rabbits and poultry, but they also contain nutritionally important pigments

Ubua, J. A., Department of Animal Science, Taraba State University, Jalingo, Nigeria.

Al-Isah, W., Department of Animal Science, Taraba State University, Jalingo, Nigeria.

Inuwa, I.,Department of Animal Science, Taraba State University, Jalingo, Nigeria.

Abdullahi, B. L.,Department of Animal Science, Taraba State University, Jalingo, Nigeria.

Ozung, P. O.,Department of Animal Science, University of Calabar, Calabar, Nigeria. 
(Esonu, 2006). Neem (Azadirachta indica) is a tropical evergreen tree native to Indian sub-continent. It has been used in Ayurvedic medicine for more than 400 years due its medicinal properties. Neem plant is an indigenous tropical plant which predominates in Nigeria. Most of the plant parts such as fruits, seeds, leaves, bark and roots contain components with proven antiseptic, antiviral and antifungal uses (Opender et al., 2004). Although, neem may have performed well as a nutrient source, there is still paucity and conflicting data on its effect on performance, haematology and serum biochemistry of rabbits. Furthermore, the prolific nature of rabbits occasioned by short gestation and generation intervals make it the animal of choice for rapid multiplication (Olubanjo, 1976). The growing acceptability of rabbit meat for its whiteness, juiciness and low cholesterol should be viewed as a plus to expanding the enterprise. In spite of all these advantages over other livestock, rabbit production has not achieved it potentials as cheap animal protein source in the tropics (Herbert and Adejumo, 1995). Research has shown that neem boosts the immune system by stimulating the production of $T$ - Cells when challenged with infections (Upadhyay, 1990). The role of medicinal plants in disease prevention or control has been attributed to antioxidant properties of their constituents usually associated to wide range of polyphenolic compounds (Demiray et al., 2009). It is a fact that changes in haematological parameters are often used to determine stresses due to nutrition and other factors. Recently, numerous research efforts have been directed at the optimal utilization of neem leaf in the feeding and medication of farm animals (Sokunbi and Egbunike, 2000; Esonu et al., 2001; Oforjindu, 2006). According to Schalm et al. (1975) blood profile of animals might be influenced by certain factors such as nutrition. Addass et al. (2012) stated that nutrition affects blood values of animals. The study was therefore designed to determine the effect of neem leaf meal on the growth performance and blood characteristics (haematology and serum chemistry) of female rabbits in a derived guinea savanna zone.

\section{Materials and methods Experimental site}

The Research was carried out at the Rabbitry Unit of Teaching and Research Farm, Taraba State University, Jalingo, Nigeria. Jalingo is located between latitude $8^{0} 53^{1}$ north of the equator and longitude $11^{0} 22^{1}$ east of the Greenwich meridian and possesses a tropical climate. Jalingo is characterized by high temperature throughout the year, because of high radiation which is evenly distributed throughout the year. Maximum temperature of about $40^{\circ} \mathrm{C}$ has been observed in the area with minimum temperature as low as $18^{\circ} \mathrm{C}$ between December and January. Mean annual temperature ranges between $26.9^{\circ}$ and $27.8^{\circ} \mathrm{C}$ (Taraba State Diary, 2018).

\section{Source and processing of Neem Leaf Meal (NLM)}

Fresh neem leaves were harvested from neem trees within the University environment. The leaves were air dried for one week (7 days) in a shade until they became crispy while still retaining the greenish colouration. The dried leaves were milled into $2 \mathrm{~mm}$ sieve size using a hammer mill.

\section{Experimental rabbits, design and management} Twenty four (24) weaned female rabbits (does) between 5 and 6 weeks old with average body weight of 600 \pm 1.05 gwere purchased from a reputable farm in Jalingo, Taraba State. Prior to the experiment, the rabbits were treated against internal and external parasites by subcutaneous injection of Ivomec according to body weight. A broad spectrum antibiotic (Oxytetracycline L.A) was administered according to body weight per rabbit. The rabbits were subjected to two weeks adjustment period, during which the control diet and water were supplied ad-libitum. Thereafter, the rabbits were weighed and randomly assigned to the four diets after weight equalization with six rabbits per treatment in a completely randomized designed (CRD). The rabbits were housed in standard cages of $40 \times 25 \times 25 \mathrm{~cm}$ in a four-tier hutch system. The hutches were cleaned daily; clean drinking water and a determined quantity of fresh feed were provided daily. The left over feeds were collected and weighed daily to determine the daily feed intake. Body weight changes were determined on a weekly basis.

\section{Experimental diets}

Four experimental diets were formulated with the NLM included at $0,5,10$, and $15 \%$ levels as dietary treatments $T_{1}, T_{2}, T_{3}$, and $T_{4}$, respectively. $T_{1}$ without NLM served as the control treatment. In addition to the formulated diets, a uniform quantity $(30 \mathrm{~g})$ of Tridax procumbens was given to all the rabbits as supplementary forage every evening throughout the feeding trial. The composition of experimental diets is presented in Table 1. 
Table 1: Composition of experimental diets

\begin{tabular}{lllll}
\hline Ingredient & $\begin{array}{l}\mathbf{T}_{1} \\
\mathbf{( 0 \%} \mathbf{~ N L M})\end{array}$ & $\begin{array}{l}\mathbf{T}_{2} \\
\mathbf{( 5 \%} \mathbf{N L M})\end{array}$ & $\begin{array}{l}\mathbf{T}_{3} \\
\mathbf{( 1 0 \% \mathbf { N L M } )}\end{array}$ & $\begin{array}{l}\mathbf{T}_{4} \\
\mathbf{( 1 5 \% \mathbf { N L } )}\end{array}$ \\
\hline Yellow maize & 36.00 & 35.00 & 34.50 & 34.00 \\
Neem leaf meal (NLM) & 0.00 & 5.00 & 10.00 & 15.00 \\
Soybean meal & 14.00 & 14.00 & 14.00 & 14.00 \\
Palm kernel cake & 10.00 & 6.00 & 6.00 & 5.00 \\
Fish meal & 1.50 & 1.50 & 1.50 & 1.50 \\
Rice offal & 13.25 & 13.25 & 13.25 & 13.25 \\
Brewers dried grain & 10.00 & 10.00 & 10.00 & 5.00 \\
Wheat offal & 12.25. & 12.25 & 7.75 & 7.75 \\
Palm oil & 1.00 & 1.00 & 1.00 & 1.00 \\
Bone meal & 1.50 & 1.50 & 1.50 & 1.50 \\
Premix* & 0.25 & 0.25 & 0.25 & 0.25 \\
Common salt & 0.25 & 0.25 & 0.25 & 0.25 \\
Total & $\mathbf{1 0 0 . 0 0}$ & $\mathbf{1 0 0 . 0 0}$ & $\mathbf{1 0 0 . 0 0}$ & $\mathbf{1 0 0 . 0 0}$ \\
Calculated nutrient levels: & & & & \\
ME (Kcal/kg) & 2578.05 & 2576.75 & 22501.10 & 22442.70 \\
Crud protein (\%) & 16.00 & 16.00 & 16.25 & 16.23 \\
Crude fibre (\%) & 8.82 & 9.27 & 9.37 & 10.18
\end{tabular}

\section{Determined nutrient levels (\%):}

\begin{tabular}{llllc} 
Dry matter & 89.25 & 88.40 & 89.30 & 87.60 \\
Crude protein & 17.69 & 18.25 & 18.50 & 17.25 \\
Crude fibre & 8.75 & 9.05 & 8.75 & 10.10 \\
Ether extract & 9.07 & 8.20 & 9.07 & 9.05 \\
Ash & 3.02 & 4.00 & 3.00 & 4.02 \\
NFE & 65.05 & 62.00 & 59.03 & 60.00 \\
\hline
\end{tabular}

${ }^{*}$ Animal Care premix provided per kg of diet: Vit. A. (12,000 I.U); D3 (3,000,000 I.U); Vit. E (30,000 mg); Vit. K3 (2500mg); folic acid (1, 000mg); Niacin (40,000mg); Vit. $B_{2}$ (20mg); Vit. $B_{\mid}(2,000 \mathrm{mg})$; Vit.B6 (3,500mg); Biotin (80mg); Cobalt (250mg); Selenium (250mg); Antioxidant (125,000mg); lodine (1,200mg); Iron (40,000mg); Manganese (70,000mg) Copper (8,000mg) Zinc $(60,000 \mathrm{mg})$ and sodium chloride $(200,000 \mathrm{mg})$

\section{Weight gain}

The weight of each individual rabbit was measured with a $5 \mathrm{~kg}$ measuring top loader scale, at first week of the experiment, and subsequently at seven days interval throughout the eight weeks duration.

Feed Intake: Daily intake was obtained as the difference between the quantity of feed served and the left over feed.

Feed Conservation Ratio: This was calculated by dividing the total feed intake by the total weight gain.

\section{Blood collection}

The blood collection was carried out at the $56^{\text {th }}$ day of the feeding trial, via the prominent ear vein with hypodermic needles and syringes. The blood was then transferred into EDTA bottles for haematological analysis according to methods reported by Ajagboana et al. (1999). Another set of blood sample was collected into labeled sterile bottles without anti-coagulant and used to determine the serum biochemical indices based on standard methods reported by Spencer and Price (1997).

\section{Statistical analysis}

Data obtained were subjected to one - way analysis of variance (ANOVA) for completely randomized design while significant means were separated using Duncan Multiple Range Test (Duncan, 1955).

\section{Results and Discussion \\ Growth performance characteristics}

Table 2 shows the growth response of weaned female rabbits to graded levels of neem leaf meal (NLM). Results revealed significant $(P<0.05)$ effect of dietary treatments on growth parameters. The final weight values were $970,950,930$ and $860 \mathrm{~g} / \mathrm{rabbits}$ for $\mathrm{T}_{1}, \mathrm{~T}_{2}$, $\mathrm{T}_{3}$, and $\mathrm{T}_{4}$ respectively. The total feed intake values were 2221, 2020, 2150 and $1700 \mathrm{~g} / \mathrm{rabbit}$, while total weight gain values were $380,330,310,310$ and 250 $\mathrm{g} / \mathrm{rabbit}$ for $\mathrm{T}_{1}, \mathrm{~T}_{2}, \mathrm{~T}_{3}$, and $\mathrm{T}_{4}$ respectively. Equally, the feed convention ratio had the following values 5.84 , $6.12,6.94$ and 6.80 for $\mathrm{T}_{1}, \mathrm{~T}_{2}, \mathrm{~T}_{3}$, and $\mathrm{T}_{4}$, respectively. The growth parameters decreased progressively in value as the NLM inclusion levels increased across the diets. Rabbits in $\mathrm{T}_{4}(15 \%$ NLM inclusion) diet recorded poor growth which conformed with lower feed intake that could be as a results of high crude fibre in the diets arising from the NLM and probably effects of bioactive compounds /anti-nutrients in the NLM which might limit feed intake with corresponding decrease in body weight (Sokunbi and Egbunike, 2000). Anti-nutrients have been reported to limit feed intake by animals and consequently, zootechnical parameters (FAO, 2002). 
Growth reduction in rabbits could be due to the presence of anti-nutritional factors in leaf meals. Ogbuewu (2008) further opined that different toxic components in neem leaf meal are responsible for depression in nutrient utilization and growth in rabbits. Similarly, odour, taste, texture and colour of finished feeds influence feed intake in animals (Arnold et al., 1980; Olayemi, 2005). The control diet without NLM was best utilized as it recorded the least feed conversion ratio (FCR) compared with other dietary treatments. The poor feed conversion ratio in the NLM diets could be attributed to the levels of crude fibre and associated residual anti-nutrient in the diets. High intake of fibrous feeds by rabbits has been reported to cause reduced feed efficiency (Gidenne et al., 2000). The minimum crude fibre level for preventing diarrhoea in rabbits has not been scientifically authenticated (Ozung, 2016). Research finding by Gidenne and Jehl (2000) showed that a sharp decline in fibre level from 19 to $9 \%$ in the diets of rabbits doubled the risk of gastro - enteritis. Cheeke (1994) reported that feeding rabbits with low fibre $(<10 \%)$ and high calorie milled diets led to high mortality due to enterotoxaemia. The recommendations for dietary fibre depend on age of the rabbit. The generally accepted fibre level for rabbits by most workers is in the excess of $10 \%$, however; Lebas et al. (1986) recommended the optimum crude fibre level for growing rabbits as $13-14 \%$. However, the fibre levels in the diets of this study were moderate $(8.82-10.18 \%)$ for growing rabbits to warrant poor FCR, the trend could be attributed to the residual anti-nutrients in the NLM diets.

Table 2: Growth response of female rabbits to graded levels of neem leaf meal (NLM)

\begin{tabular}{|c|c|c|c|c|c|}
\hline Parameter & $\mathrm{T}_{1}(0 \%)$ & $\mathrm{T}_{2}(5 \%)$ & $\mathrm{T}_{3}(10 \%)$ & $\mathrm{T}_{4}(15 \%)$ & SEM \\
\hline Average initial weight (g) & 590.00 & 620.00 & 620.00 & 610.00 & 1.22 \\
\hline Average final weight gain ( $\mathrm{g}$ & $970.00^{\mathrm{a}}$ & $950.00^{\mathrm{ab}}$ & $930.00^{b}$ & $860.00^{c}$ & 1.95 \\
\hline Total feed intake (g) & $2221.00^{\mathrm{a}}$ & $2020.00^{b}$ & $2150.00^{b}$ & $1700.00^{c}$ & 0.63 \\
\hline Total weight gain $(\mathrm{g})$ & $380.00^{\mathrm{a}}$ & $330.00^{b}$ & $310.00^{c}$ & $250.00^{d}$ & 3.72 \\
\hline Feed conversion ratio & $5.84^{b}$ & $6.12^{\mathrm{ab}}$ & $6.94^{\mathrm{a}}$ & $6.80^{\mathrm{a}}$ & 0.36 \\
\hline
\end{tabular}

\footnotetext{
${ }^{\mathrm{abc}}$ Means within the same row with different superscripts differ significantly $(\mathrm{P}<0.05)$.

NLM - Neem Leaf Meal

SEM - Standard error of the mean
}

\section{Haematological parameters and serum biochemical indices}

The haematological parameters of female rabbits fed NLM are presented in Table 3. Results revealed that all haematological parameters were significantly $(P<0.05)$ influenced by dietary treatments, but the haemoglobin $(\mathrm{Hb})$, red blood cell counts (RBC), packed cell volume (PCV), White blood cell counts (WBC) and differentials (lymphocytes and neutrophils) had values that were within the normal reference ranges for rabbits reported by Schalm et al. (1975); Mitruka and Rawnsley (1997); Medirabbit (2011). This implies that different levels of NLM in this study had no adverse effect on the haematological parameters. The female rabbits fed $10 \%$ neem leaf meal diet had the highest haemoglobin content which fell within the range of $9.4-17.4 \mathrm{~g} / \mathrm{dl}$ reported by Mitruka and Rawnsley (1977) and Ross et al. (1978). Haemoglobin range of 9.4. - 17.4g/dl has also been reported by Kronfield and Mediway (1975) and Hewitt et al. (1989) for healthy rabbits. The haemoglobin content reflects the physiological responsiveness of animals to their internal and external environment which include feed and feeding (Esonu, et al., 2001). The red blood cell counts (RBC) recorded in this study were within the recommended ranges reported by Mitruka and Rawnsley (1997); Hewitt et al. (1989) for healthy rabbits. This implies that up to $15 \%$ neem leaf meal may not have any deleterious effect on erythropoiesis in rabbits. The packed cell volume was within the range of 25 $45 \%$ reported by Mitruka and Rawnsley (1997) for healthy rabbits but declined with increasing levels of NLM. The fall in the PCV value beyond the control diet indicated that NLM is low in protein quality or low in minerals (micro and macro). This could equally be linked to the findings of Opender et al. (2004) that Neem Leaf Meal directly or indirectly inhibits the secretion of trypsin by the enzymes secreting cells of the gut (alimentary tract). The slight variation in white blood cell counts observed at higher levels of NLM inclusion in diet in this study may be attributed to nutrient imbalance, poor nutrient utilizations and residual anti - nutrients. The neutrophils are concerned with the immunological defence against pathogens; this implies that the ingestion of NLM at these levels did not trigger the production of this blood components. The non-elevated values of lymphocytes suggest that the animals were clinically healthy. The mean corpuscular haemoglobin $(\mathrm{MCH})$ values obtained (Table 3) in this study at 10 and $15 \%$ levels of NLM diet were above the normal range 19.2 - $29.5 \mathrm{pg}$ reported by Hewitt et al. (1989) but fell within the range of $58-79.6$ pg reported by Kronfield and Mediway (1975). The mean corpuscular haemoglobin concentration (MCHC) values at 10 and $15 \%$ levels of NLM diets were slightly higher than the normal range of 31.1-37.0 g/l reported by Hewitt et al. (1989) even though the rabbits did not show any obvious sign of abnormality. MCHC value is known to be the most accurate and absolute index indicating anaemic condition in animals (Thompson, 2006); slight over elevation of the MCHC values might infer adverse effect on haemoglobin production by the NLM diets and iron utilization by the rabbits. This however did not manifest as normocytic anaemia as a result of lack of normocytic and normochromic red cells in the rabbits (Thompson, 2006). The serum biochemical constituents of the rabbits are shown in Table 3 . All serum biochemical indices were not significantly $(P>0.05)$ affected by dietary treatments, implying that NLM up to $15 \%$ 
inclusion level had no interference in the alkaline balance of tissue fluids in the rabbits. This finding was in agreement with the report of Adeyina et al. (2008) who fed synthetic or extracted theobromine to rabbits. The serum urea and creatinine levels were within the normal ranges of 8.1-25.0 $\mathrm{g} / \mathrm{l}$ and 1.4-16.6 g/l respectively reported by Kronfield and Mediway (1975) for rabbits. The creatinine levels obtained for rabbits fed
NLM based diets were in consonance with the findings of Omole and Sonaiya (1981), and suggested that there was no muscle wasting or catabolism of the muscle tissues, thus the animals were not surviving at the expense of body reserves (Bell et al., 1992). Accordingly, neem leaf meal and associated antinutrients did not cause any deleterious effect on the serum metabolites in female rabbits.

Table 3: Blood characteristics of female rabbits fed graded levels of neem leaf meal (NLM)

\begin{tabular}{|c|c|c|c|c|c|c|}
\hline Parameter & $\mathrm{T}_{1}(0 \%)$ & $\mathrm{T}_{2}(5 \%)$ & $\mathrm{T}_{3}(10 \%)$ & $\mathrm{T}_{4}(15 \%)$ & SEM & Ref. ranges* \\
\hline \multicolumn{7}{|l|}{ Haematology } \\
\hline $\mathrm{HB}(\mathrm{g} / \mathrm{dl})$ & $10.30^{\mathrm{a}}$ & $7.00^{\mathrm{ab}}$ & $10.80^{\mathrm{a}}$ & $9.90^{\mathrm{b}}$ & 0.78 & $(10-15)$ \\
\hline PCV (\%) & $18.90^{\mathrm{a}}$ & $13.50^{\mathrm{b}}$ & $22.60^{\mathrm{a}}$ & $19.90^{\mathrm{a}}$ & 1.17 & $(30-50)$ \\
\hline $\operatorname{RBC}\left(\times 10^{12} / L\right)$ & $2.33^{b}$ & $3.00^{\mathrm{ab}}$ & $3.15^{\mathrm{a}}$ & $2.00^{\mathrm{ab}}$ & 0.18 & $(4-8)$ \\
\hline $\mathrm{MCH}$ (pg/cell) & $39.10^{\mathrm{a}}$ & $24.00^{c}$ & $33.50^{b}$ & $41.50^{\mathrm{a}}$ & 1.31 & $(19-22)$ \\
\hline $\mathrm{MCHC}(\mathrm{g} / \mathrm{dl})$ & $52.50^{\mathrm{a}}$ & $36.00^{\mathrm{b}}$ & $43.90^{\mathrm{ab}}$ & $54.00^{\mathrm{a}}$ & 3.22 & $(30-35)$ \\
\hline WBC $\left(\times 10^{9} / \mathrm{L}\right)$ & $5.95^{\mathrm{b}}$ & $4.00^{b}$ & $11.30^{\mathrm{a}}$ & $5.99^{c}$ & 1.27 & $(5-12)$ \\
\hline Lymphocytes (\%) & $54.00^{\mathrm{b}}$ & $74.50^{\mathrm{a}}$ & $70.00^{\mathrm{a}}$ & $50.00^{\mathrm{b}}$ & 4.39 & $(30-85)$ \\
\hline Neutrophils (\%) & $17.00^{\mathrm{b}}$ & $12.50^{\mathrm{C}}$ & $22.06^{\mathrm{b}}$ & $41.00^{\mathrm{a}}$ & 4.39 & $(20-75)$ \\
\hline \multicolumn{7}{|l|}{ Serum biochemistry } \\
\hline Creatinine $(\mathrm{mmol} / \mathrm{l})$ & 29.70 & 29.95 & 30.50 & 30.51 & 1.12 & $(53-124)$ \\
\hline Urea $(\mathrm{mmol} / \mathrm{l})$ & 0.48 & 0.59 & 0.61 & 0.68 & 0.06 & - \\
\hline Bicarbonate $(\mathrm{mmol} / \mathrm{l})$ & 10.50 & 8.75 & 7.90 & 8.00 & 0.67 & - \\
\hline Sodium (mmol/l) & 42.00 & 40.00 & 42.50 & 41.50 & 1.37 & $(130-155)$ \\
\hline Potassium (mmol/l) & 0.95 & 0.78 & 0.78 & 0.75 & 0.05 & $(4.00-6.50)$ \\
\hline Chloride $(\mathrm{mmol} / \mathrm{l})$ & 37.50 & 34.50 & 35.00 & 35.00 & 1.17 & $(92-120)$ \\
\hline
\end{tabular}

\section{CONCLUSION AND RECOMMENDATION}

Results obtained from this study revealed that neem leaf meal (NLM) can be included in the diets of female rabbits without any deleterious effect on the growth performance, haematological indices and serum biochemical constituents. However, for optimum growth response of the rabbits and haematopoietic processes, $10 \%$ NLM is hereby recommended for inclusion in diets meant for rabbits. Further studies on blood characteristics of rabbits are suggested with much higher levels of NLM.

\section{REFERENCES}

Addass, P.A., David, D.J., Edward, A., Zira, K.E. and Midak, A., 2012. Effect of age, sex and management system on some haematological parameters of intensively and semi intensively kept chickens in Mubi, Adamawa State, Nigeria. Iranian Journal of Applied Animal Science, 2(3):277- 282.

Adeyina, A. O., Oguntoye, S. O., Olatunde, A. O. and Apata, D. F., 2008. Comparative effects of theobromine and cocoa bean shell (CBS) extract on the performance, serum constituent profile and physiological parameters in rabbits. Global Journal of Pure and Applied Sciences, 14(3): $253-255$.

Aduku, A. O. and Olukosi, J.O., 1990. Rabbit Management in the Tropics: production, processing, utilization, marketing, economics, practical training, research and prospects. Living Books GU Publication, Abuja, FCT, Nigeria, 150Pp.

Ajagboana, O.P., Onifade, K.I., and Suleiman, U., 1999. Haematological and biochemical changes in rats given extracts of Calotropis procera. Sokoto Journal of Veterinary Science, 1: $36-42$.

Arnold, G. W., DeBoer, E.S. and Bound, C.A.P., 1980. The influence of odour and taste on food preferences and food intake of sheep. Australian Journal of Agricultural Research, 31: 571-578. 
Bell, G. H., Emshen, S. D. and Paterson, C. R., 1992. Textbook of Physiology and Biochemistry, Churchill Livingstone Publishers, Edinburgh, Pp. $229-239$.

Cheeke, P. R., 1986. Potentials of rabbit production in tropical and subtropical Agricultural Systems. Journal of Animal Science, 63 (5): 151- 158.

Cheeke, P.R., 1994. Nutrition and nutritional diseases. In: Manning, P.J., Ringler, D. H. and Newcomer, C. E. (Eds.). The Biology of laboratory rabbit, 2nd edn. Academic Press, New York.

Demiray, S. M., Pintado, E. and Castro, P.M.L., 2009. Evaluation of phenolic profiles and antioxidant activities of Turkish medicinal plants: Thia argentea, Crataegi folium leaves and polygonuim roots. World Academic Science and Engineering Technology, 54:31 - 37.

Duncan, D.B., 1955. Multiple ranges and multiple F-test Biometrics. 11:1- 42.

Esonu, B. O., Emenalon, O.O.,Udedibie, A. B. I., Herbert, U., Ekpor, C. F., Okoli, I. C. and Ihekwumere, F. C., 2001. Performance and blood chemistry of weaner pigs fed raw mucuna (velvet bean) meal. Tropical Animal Production Investigation (TAPI), 4: $49-54$.

Esonu, B.O., 2006. Animal Nutrition and Feeding: A Functional Approach. $2^{\text {nd }}$ Edition,Memory Press, Owerri, Imo State, Nigeria, Pp. 87- 88.

FAO 2002. Food and Agriculture Organization. World agriculture: towards 2015/2030. Summary report. Rome, Food and Agriculture Organization of the United Nations, 2002.

Gidenne, T. and Jehl, N., 2000. Caecal microbial activity of young rabbits. Incidence of fibre deficiency and feed intake. In: Blanco, A. (ed.), $7^{\text {th }}$ World Rabbit Congress, Universidad Politecnica de Valencia, Spain, Pp. $233-239$.

Gidenne, T., Pinheiro, V. and Falcaoe- Cunha, L., 2000. A Comprehensive Approach of Rabbit Digestion: consequences of a reduction in dietary fibre supply. Livestock Production Science, 64: 225 - 237.

Herbert, U. and Adejumo, D.O., 1995. Construction and evaluation of Artificial Vagina for collecting rabbit semen. Delta Agriculture, 2:99108.

Hewitt, C. J., Jones, D. J., Savory, J. and Wills, M, R., 1989. Normal Biochemical and Haematological values in New Zealand white rabbits. Clinical Chemistry, 35 (8): 1777 - 1779.

Kronfield, O.W. and Mediway, N.C., 1975. Blood Chemistry, In: Textbook of Veterinary and Clinical Pathology published by Williams and Williams Company, Baltimore, Pp. 18 - 96.
Lebas, F., Coudert, P., Rouvie, R. and Rochambeau, H. D., 1986. The rabbit husbandry, health and production. FAO Animal Production and Health Series, No. 21, Rome, Italy, Pp. 43 - 44.

Mahmud, M., Shaba, P., Gana, J. and Abdulsalam, W., 2015. Growth Performance of growing quails fed graded levels of Neem leaf meal. International Journal of Applied Research (2): 4 - 7.

Medirabbit 2011.Complete blood count and reference values in rabbits. http://www.medirabbit.com/EN/Hematolo gy/blood_chemistry.htm, retrieved 13/11/2018, 9:05am

Mitruka, B. M. and Rawnsley, H. M., 1997. Clinical, biochemical and haematological reference values in normal experimental animals, Mason Publishing Press, $\quad$ U.S.A., 144Pp.

Ogbuewu, I.P., 2008. Physiological responses of rabbits fed graded levels of neem (Azadirachta indica) leaf meal. M.Sc. Thesis, Federal University of Technology, Owerri, Nigeria.

Ogbuewu, I. P., Okoli, I. C. and Iloje, M. U., 2010. Linear growth and reproductive tract morphometry in rabbit does fed leaf meal of Neem (Azadirachta indica A. Juss). African Journal of Biomedical Research 13: 207 - 212. Retrieved from www.ajbrui.net on Thursday, $13^{\text {th }}$ December, 2018 at $11: 45 a m$.

Oforjindu, O., 2006. The toxicity of graded levels of Neem (Azadirachta indica) leaf meal. B. Agric. Tech. Project Report, Federal University of Technology, Owerri, Nigeria.

Olayemi, T.B., 2005. Effect of wild sunflower leaf meal on growth performance, blood and carcass characteristics of weaner pigs. M.Tech. Thesis. Department of Animal Production and Health. Ladoke Akintola University of Technology, Ogbomosho, Nigeria.

Olubanjo, O., 1976. The nutritive value of hay from four grass species cut at three different stages of growth in Ibadan, Nigeria. Nigeria Journal of Animal Production, 14:33-137.

Omole, T.A. and Sonaiya, E.B., 1981. The effect of protein source and methionine supplementation of cassava peels meal on growing rabbits. Nutrition Reports International, 23(4):779 - 737.

Opender, K. Shankar, I.S. and Kafil, R.S., 2004. The effect of Neem allelochemicals on nutritional physiology of larval spodoptera litura. Journal of Entomologia Experimentalis et Applica, 43-50.

Ozung, P.O., 2016. Performance and physiological responses of rabbits to processed cocoa (Theobroma cacao L.) pod husk meal based - 
diets. Doctorate Thesis, Department of Animal Science, University of Calabar, Calabar, Nigeria, 265Pp.

Ozung, P. O.,Oko, O. O. K., Agiang, E. A., Eburu, P. O., Evans, E. I. and Ewa, C. E., 2017. Growth performance and apparent nutrient digestibility co - efficients of weaned rabbits fed diets containing different forms of Cocoa Pod Husk Meal. Agricultural and Food Sciences Research, 4(1): 8 - 19, DOI: 10.2448/journal.512.2017.41.8.19.

Ross, J.G., Christies, G. Halliday, W.G., and Jones, R.M., 1978. Haematological and blood chemistry comparison values for clinical pathology in poultry. Veterinary Records 102: 29 - 31.

Schalm, O.W., Jain, N.C and Caroll, E.I., 1975. Veterinary Haematology. $3^{\text {rd }}$ edn. Lea and Fabiger, Philadelphia.

Sokunbi, O.A and Egbunike, G.N., 2000. The performance of growing rabbits fed diets containing sun cured Neem leaf meal. Proceedings of the $5^{\text {th }}$ Annual Conference of
Animal Science Association of Nigeria (ASAN), held in Port Harcourt, Nigeria, Sept. $19-22$, Pp.113-116.

Spencer, K. and Price, C.P., 1997. Chemical analysis of bilirubin in biological fluids. Annals of Clinical Biochemistry, 14:105-115.

Taraba State Diary 2018. Taraba State Diary. Jalingo, Nigeria: Yearly Publication by the Ministry of Home Affairs, Government of Taraba State, Nigeria.

Thompson, R.B., 2006. A short textbook of Haematology, $7^{\text {th }}$ edition, Garden City Press Ltd. Letchworth, Hertfordshire, Pp. 217.

Unigwe, C.R., Nwakpo, P.U. and Uchewa, E. N., 2009. Effect of bitter cola seed meal on growth performance of rabbits. International Journal of Zoology, 1 (1): 42- 46.

Upadhyay, C., 1990. The medicinal properties of Neem (Azadirachta indica) tree. In: Animal Pharmacology, $2^{\text {nd }}$ edn. Longman Publishers, England. 